\title{
Adhesion Abilities of Lactobacillus Plantarum Strains Isolated from Nigerian Fermented Maize Food - Akamu
}

\author{
Patience Chisa Obinna-Echem ${ }^{1,2}$ \\ ${ }^{1}$ School of Biomedical and Biological Sciences, Plymouth University, Plymouth PL4 8AA, UK \\ ${ }^{2}$ Food Science and Technology, Rivers State University of Science and Technology, P.M.B 5080, Port Harcourt, \\ Rivers State, Nigeria \\ Correspondence: Obinna-Echem, Patience Chisa, Rivers State University of Science and Technology, P.M.B \\ 5080, Port Harcourt, Rivers State, Nigeria. E-mail: chisanupat@yahoo.com
}

Received: April 30, 2017 Accepted: June 16, 2017 Online Published: August 21, 2017

doi:10.5539/jfr.v6n5p50 URL: https://doi.org/10.5539/jfr.v6n5p50

\begin{abstract}
Two strains of Lactobacillus plantarum isolated from akamu a Nigerian fermented maize food were investigated for probiotic potential based on: adhesion to hydrocarbons (hydrophobicity), porcine mucin and epithelial cell models. Gelatinase and haemolytic activities of the $L$. plantarum isolates were also studied. Adhesions to mono polar solvents $(>22 \%)$ were significantly $(\mathrm{p} \leq 0.05)$ higher than the $n$-alkanes $(<13 \%)$ with significant maximal affinity (35\%) for chloroform an acidic solvent. The general order of affinity was chloroform $>$ ethyl acetate $>$ hexadecane $>$ hexane. NGL7 had significantly $(\mathrm{p} \leq 0.05)$ the highest affinity for all the solvents. Both $L$. plantarum strains had significant adhesions to porcine mucin $\left(\geq 6.51 \log _{10} \mathrm{CFU} \mathrm{mL} \mathrm{m}^{-1}\right)$ after $2 \mathrm{~h}$ at $37^{\circ} \mathrm{C}$. Viable counts on Caco-2 cells were 5.13 and $5.53 \log _{10} \mathrm{CFU} \mathrm{mL}{ }^{-1}$ for NGL7 and NGL5 respectively. The $L$. plantarum strains possessed significant adhesion abilities: adhesion to hydrocarbons, porcine mucin and Caco-2 cells with no gelatinase and haemolytic activity. This suggested that the $L$. plantarum strains isolated from the Nigerian fermented maize food -akamu would be able to adhere to the intestinal mucosa and epithelial cells for beneficial health effects without posing any risk.
\end{abstract}

Keywords: Lactobacillus plantarum, hydrophobicity, adhesion, Caco-2 cells, gelatinasis; haemolysis

\section{Introduction}

Adhesion of probiotic bacteria to the intestinal mucosal surfaces and epithelial cells and cell lines are among the main selection criteria for probiotic microorganisms (FAO/WHO, 2002). Adhesion ability of probiotic bacteria offers competitive advantage important for bacterial persistence in the gut (Vinderola \& Reinheimer, 2003). Bacterial cell surface hydrophobicity is an important factor that governs adhesion of bacteria to various surfaces (Liu et al., 2004; Zita \& Hermansson, 1997). it represents an attractive force between cells and/or inert surfaces principally due to the role of electron-donor/electron-acceptor interactions between the two surfaces (Bellon-Fontaine, Rault, \& van Oss, 1996). Bacterial cell surface hydrophobicity has often been assessed by adhesion to solvents or hydrocarbons (Del Re, Sgorbati, Miglioli, \& Palenzona, 2000; Kos et al., 2003; Mathara et al., 2008; Schillinger, Guigas, \& Heinrich Holzapfel, 2005; Vinderola \& Reinheimer, 2003), based on the comparison between bacterial cell affinity to a monopolar and a polar solvent. The monopolar solvent could be acidic (electron acceptor) or basic (electron donor) but must have similar van der Waals properties (Bellon-Fontaine et al., 1996). High cell surface hydrophobicity has been correlated to increased cell-to-cell adhesion (Del Re et al., 2000; Kos et al., 2003; Schillinger et al., 2005) and suggested to play significant role in interaction with organic mucin layer of the gut (Mathara et al., 2008) and adhesion to epithelial cells (Schillinger et al., 2005).

The epithelial cells of the human digestive tract is overlaid with mucus; a biochemically complex layer containing glycoproteins, antimicrobial peptides, immnoglobulins, lipids and electrolytes (Juge, 2012). The main component being high molecular weight surface active glycoproteins called mucins (Jonsson, Ström, \& Roos, 2001; Svensson \& Arnebrant, 2010). The gastrointestinal mucus is divided into two layers; an outer loose easily removable layer and an inner layer firmly attached to the epithelium (Juge, 2012). The outer mucus layer harbours glycan-rich domains that provide preferential binding sites and energy for bacterial proliferation while the inner mucus layer protects the underlying intestinal epithelia layer from intestinal contents such as corrosive 
acid and pepsin of gastric juice and guards the host against infections by pathogens ( Zhou, Gopal, \& Gill, 2001; Juge, 2012; Uchida et al., 2006). The outer mucus layer is continually being degraded and new components constantly secreted. For prolonged persistence that allows time for exertion of healthful benefits, bacterial adhesion to the mucus layer need to reach the epithelial cells to prevent quick dislodging and washing away by luminal content (Kirjavainen, Ouwehand, Isolauri, \& Salminen, 1998). The assessment of adhesion properties of probiotic bacteria have been achieved through in-vitro adherence to mucus and epithelia layers using mucin extracts from human and animals, Caco-2 and HT-29 cells and human intestinal Int-407 (ATCC CCL 6) cells as intestinal models (Baccigalupi et al., 2005; Kalui, Mathara, Kutima, Kiiyukia, \& Wongo, 2009; Lin et al., 2011; Monteagudo-Mera et al., 2012; Wang et al., 2008).

Just as microbial adhesion to intestinal mucosa and epithelial cells is an important probiotic characteristic; their degradation is considered a potential virulence factor (Apostolou et al., 2001; FAO/WHO, 2002). Microorganisms with extensive mucin-degrading activity would have the potential to invade the host, facilitate mucosal penetration by potential pathogens and cause cessation of the underlying epithelial cell lines. Theoretically, mucinolysis can be defined by changes in the carbohydrate and/or protein content of ethanol-precipitated mucin portions (Zhou, Gopal, \& Gill, 2001). The in-vitro ability of bacteria to hydrolyse gelatine would imply their ability to derange the protective mucus lining of the GIT, while the ability to breakdown red blood cells would cause cessation of the underlying epithelial layer. Although most studies had been with intestinal and dairy isolates, there is increasing interest not just in the development of food products containing beneficial Lactobacillus strains but the characterisation of non-intestinal isolates for possible health-enhancing effects.

Аkати is a lactic acid fermented cereal-based food that constitutes a major infant complementary food, serves as a component of adult main meals and also an important food for convalescence in most Africa countries. Lactobacillus plantarum is one of the main Lactic acid bacteria associated with spontaneous fermentation of akaти (Obinna-Echem, Kuri, \& Beal, 2014). To be able to develop akamu for more than its nutritional value to that of health enhancing benefits would require the characterization of the fermenting microorganism for probiotic potentials. This study was therefore aimed at the characterisation of two strains of L. plantarum isolated from akати a Nigerian fermented maize food for possible probiotic potential based on: adhesion to hydrocarbons (hydrophobicity), adherence to mucin and epithelial cell models and, gelatinase and haemolytic activities.

\section{Method}

\subsection{Microorganism and Inoculum Preparation}

The two L. plantarum strains: NGL5 and NGL7 characterised in this study were previously isolated from akamu a Nigerian traditionally fermented maize food and identified using both conventional and molecular methods by (Obinna-Echem et al., 2014). The commercial probiotic strain (LpTx) was isolated from a probiotic food supplement obtained from Health Food Shop, Rickard Lanes', Plymouth City Centre, UK, using the same method described by Obinna-Echem et al., (2014). L. reuteri NCIB 11951 was obtained from stock culture in the Microbiology laboratory of Plymouth University.

The lactic acid bacteria (LAB) were cultivated on de Man, Rogosa and Sharpe (MRS) agar with incubated at $37^{\circ} \mathrm{C}$ for $24 \mathrm{~h}$. MRS broth was used for the LAB broth cultures. A distinct colony from the agar plate culture was inoculated into $10 \mathrm{~mL}$ of broth and incubated at $37^{\circ} \mathrm{C}$ without agitation for $18-20 \mathrm{~h}$. The cultures were harvested by centrifugation (Hettich Zentrifugen Rotina $46 \mathrm{~S}$, Tuttlingen, Germany) at $4000 \times \mathrm{g}$ for $10 \mathrm{~min}$ and washed twice in phosphate buffered saline (PBS) $(\mathrm{pH} 7.3 \pm 0.2)$ and re-suspended in PBS such that $1 \mathrm{~mL}$ of inoculum produced $9 \log _{10} \mathrm{CFU} / \mathrm{mL}$. The media and the diluent used were obtained from Oxoid Limited (Basingstoke, Hampshire, UK) (Obinna-Echem et al., 2014).

\subsection{Hydrophobicity}

Hydrophobicity was demonstrated as described Bellon-Fontaine et al., (1996) with some modifications. The pairs of solvents used were Chloroform and hexadecane, and ethyl acetate and hexane. Equal volume $(2 \mathrm{~mL})$ of bacterial suspensions and the individual solvents were mixed by vortexing for $120 \mathrm{~s}$. After 20 min of incubation at $22-24{ }^{\circ} \mathrm{C}$ for complete separation of the two phases, the absorbance of the aqueous phase $(1 \mathrm{~mL})$ at $600 \mathrm{~nm}$ was measured and the decrease in the absorbance of the aqueous phase was taken as a measure of cell surface hydrophobicity, expressed as follows:

$$
\left(1-A / A_{o}\right) \times 100
$$


where $\mathrm{A}$ and $\mathrm{A}_{\mathrm{o}}$ were absorbance values before and after addition of solvents.

\subsection{Adhesion to Porcin Mucin}

Adhesion to mucin was determined using the method of Roos, Karner, Axelsson, \& Jonsson (2000) and Jonsson et al. (2001) with some modifications. Briefly, $100 \mathrm{~mL}$ of mucin (porcine stomach Type II, Sigma-Aldrich, Gillingham, Dorset, England) solution at a concentration of $100 \mu \mathrm{g} \mathrm{mL}^{-1}$ in $50 \mathrm{mmol} \mathrm{L}^{-1} \mathrm{Na}_{2} \mathrm{CO}_{3}$ in Maxi Sorp surface Nunc-Immunomicrotitre wells (Life Technology, Paisely, UK) were incubated at $4^{\circ} \mathrm{C}$ overnight. The wells were blocked with phosphate buffered saline supplemented with $0.05 \%$ Tween 20 (PBST) at room temperature $\left(22 \pm 2^{\circ} \mathrm{C}\right)$ for $1 \mathrm{~h}$ and thereafter washed with the same buffer.

The bacteria were grown in MRS broth at $37^{\circ} \mathrm{C}$ for $16 \mathrm{~h}$, washed once with PBST and re-suspended in the same buffer to an optical density of 0.5 at $600 \mathrm{~nm}$. In one experiment, $100 \mu \mathrm{L}$ of the bacterial cell suspensions for each test organism were added into the wells of one of the plates for absorbance measurement and to another set of plates for microbial enumeration. The plates were incubated on an orbital platform shaker (IKA vibrax-VXR S17, Staufen, Germany) at $40 \mathrm{rpm}$ for $1 \mathrm{~h}$ at $37^{\circ} \mathrm{C}$. Thereafter, the content of the wells were aspirated and the wells were washed thrice with PBST to remove unbound bacterial cells. The plates for absorbance measurement were left to dry in the incubator at $30^{\circ} \mathrm{C}$ for 30 munities and the absorbance values $\left(\mathrm{OD}_{403} \mathrm{~nm}\right)$ were measured in a VersaMax ELISA microplate reader (Molecular Devices, Wokingham, Berkshire, UK). Bound bacterial cells for microscopic examination were estimated under phase contract inverted microscope (Olympus CK30, Yaug-Guan St., Taipei, Tiawan) at a magnification of $\mathrm{x} 4000$.

Each batch of experiment included control wells (mucin coated wells with PBST only) and L. reuteri NCIB 11951 was used as standard (Aleljung et al., 1994). Wells that were not coated with mucin but inoculated with bacterial cell suspension were also examined, to ascertain whether the bacteria could bind to the walls of the wells. Adhesion was expresses as:

$$
\left(O D_{m l}-O D_{m}\right) / O D_{m}
$$

Where $O D_{m l}$ and $O D_{m}$ represented $O D$ of mucin coated wells inoculated with the LAB and the mucin with only the buffer solution. To estimate the number of adhered bacterial cells, the bound cells after washing were lifted with $1 \mathrm{~mL}$ of buffer into $9 \mathrm{~mL}$ of PBST. $1 \mathrm{~mL}$ of appropriate dilutions was plated on MRS agar with incubated at $37^{\circ} \mathrm{C}$ for $24 \mathrm{~h}$.

\subsection{Adhesion to Caco-2 cells}

\subsubsection{Caco-2 Cell Culture}

Caco-2 cells were grown according to the method of Xie, Zhou, \& Li, (2012). Briefly, Caco-2 cells were grown at $37^{\circ} \mathrm{C}$ in $5 \% \mathrm{CO}_{2}-95 \%$ air atmosphere (Thermo Scientific Forma Steri-Cult $\mathrm{CO}_{2}$ incubator, Waltham, Massachusetts, USA) in Dulbecco modified Eagle's minimal essential medium (DMEM) containing L-glutamine $\left(2 \mathrm{mmol} \mathrm{L}^{-1}\right.$ ), supplemented with $10 \%$ (v/v) fetal calf serum, $1 \%(\mathrm{v} / \mathrm{v})$ non-essential amino acids, $100 \mathrm{U} \mathrm{mL}^{-1}$ penicillin and $0.1 \mathrm{mg} \mathrm{mL}^{-1}$ streptomycin. The Caco-2 monolayers were prepared by seeding in $500 \mu \mathrm{L}$ of cells (c. $5 \log _{10}$ cells $\mathrm{mL}^{-1}$ ) into six-well tissue culture plates (Fisher Scientific, Loughborough, UK) that were incubated for 21 days, with daily changing of the cultured medium to replenish nutrients and maintain the correct $\mathrm{pH}$.

\subsubsection{Cac0-2 Adhesion Assay}

Adhesion assay was performed following the method of Maragkoudakis et al. (2006). The growth medium in six-well tissue culture plates of Caco-2 monolayers was aspirated and the cells washed twice with PBS (pH 6.8). Subsequently, $100 \mu \mathrm{L}$ of bacterial cell suspension $\mathrm{OD}_{600 \mathrm{~nm}}\left(\right.$ c. $8 \log _{10} \mathrm{CFU} \mathrm{mL} \mathrm{mL}^{-1}$ ) was added to the Caco-2 monolayers. After $1 \mathrm{~h}$ of incubation at $37^{\circ} \mathrm{C}$ in $5 \% \mathrm{CO}_{2}$, the bacterial cells were aspirated and the monolayers washed 6 times with PBS to release unbound bacteria. Adhered bacterial cells for viable count were lifted with 1 $\mathrm{mL}$ of $1 \%$ Triton X-100 (BDH, England) into $9 \mathrm{~mL}$ of PBS and enumerated.

\subsection{Gelatinase and Haemolytic Activities}

Gelatinase activity of the L. plantarum strains was investigated using the method of Harrigan, (1998). Bacterial cell suspension $(5 \mu \mathrm{L})$ were spotted on Nutrient agar (Oxiod, Basingstoke, England) supplemented with $0.4 \%$ gelatine (Merck, Germany) and incubated at $37^{\circ} \mathrm{C}$ for $2-7$ days in anaerobic jars with aenarobic gas jackets (AnaeroGen, Oxiode, Basingstoke, England). Thereafter the plates were flooded with $8 \mathrm{~mL}$ of saturated $\mathrm{NH}_{3} \mathrm{SO}_{4}$ and observed for clear zones as positive gelatinase activity. For haemolytic activity, a colony from $18 \mathrm{~h}$ plate culture of the L. plantarum strains, E. coli NCTC 11560 and S. Enteritidis NCTC 5188 was streak plated on blood agar composed of Columbia agar base (Oxiod, Basingstoke, England) supplemented with 5\% defibrinated 
sheep blood (TCS Biosciences, Buckingham, UK). The plates were incubated anaerobically at $37^{\circ} \mathrm{C}$ for $48 \mathrm{~h}$. The pathogens served as control.

\subsection{Statistical Analysis}

Data obtained were statistically analysed using Minitab (Release 16.0) Statistical Software English (Minitab Ltd. Coventry, UK). Statistical differences and relationship among variables were evaluated by analysis of variance (ANOVA) under general linear model and Tukey pairwise comparisons at 95\% confidence level. Relationship between the variables utilised multiple regressions and correlations (Zar, 1999). Interpretations of the correlation results were made using $\alpha$-level of 0.01 , in which p-values less than or equal to 0.01 signified that the correlation was not zero.

\section{Results and Disscussion}

\subsection{Hydrophobicity}

Table 1. Adhesion (\%) of Lactobacillus plantarum strains (NGL5, NGL7 \& LpTx) to solvents

\begin{tabular}{llllll}
\hline $\boldsymbol{L}$. & Solvents & & & & \multirow{2}{*}{ *Mean } \\
\hline plantarum & Chloroform & Hexadecane & Ethyl acetate & Hexane & \\
\hline NGL5 & $18.09 \pm 0.34^{\mathrm{e}}$ & $5.86 \pm 0.43^{\mathrm{h}}$ & $9.71 \pm 0.90^{\mathrm{g}}$ & $5.59 \pm 0.19^{\mathrm{h}}$ & 9.8 \\
NGL7 & $63.58 \pm 0.57^{\mathrm{a}}$ & $25.75 \pm 0.61^{\mathrm{c}}$ & $32.76 \pm 0.89^{\mathrm{b}}$ & $14.78 \pm 0.02^{\mathrm{f}}$ & 34.2 \\
LpTx & $23.48 \pm 0.30^{\mathrm{d}}$ & $6.47 \pm 0.48^{\mathrm{h}}$ & $23.88 \pm 0.81^{\mathrm{d}}$ & $10.07 \pm 0.46^{\mathrm{g}}$ & 16.0 \\
*Mean & 35.1 & 12.7 & 22.1 & 10.1 & \\
\hline
\end{tabular}

Values with same superscript do not differ significantly ( $\mathrm{p} \leq 0.05)$. N=3 $\pm \mathrm{SD}$

NGL5 and NGL7 - L. plantarum strains isolated from akamu-a Nigerian fermented maize food

LPTX - Commercial probiotic strain isolated from a probiotic food supplement

In Table 1, there was significant variation in the ability of the L. plantarum strains to adhere to the solvent pairs chloroform/hexadecane and ethyl acetate/hexane. NGL7 had significantly $(\mathrm{p} \leq 0.05)$ the highest affinity for all the solvents while NGL5 had the least affirnity. The values were $63.58-18.09,25.75-5.86,32.76-9.71$ and 14.78 - 5.59\% for chloroform, hexadecane, ethyl acetate and hexane respectively. Adhesions to the mono polar solvents: chloroform $(35.1 \%)$ and ethyl acetate $(22.1 \%)$ were significantly $(\mathrm{p} \leq 0.05)$ higher than the $n$-alkanes: hexadecane $(12.7 \%)$ and hexane $(10.1 \%)$ with significant maximal affinity for chloroform an acidic solvent. The general order of display of affinity was chloroform $>$ ethyl acetate $>$ hexadecane $>$ hexane.

Hydrophobic cell surface properties of the L. plantarum strains were observed to be that of favourable acid-base interaction with increased affinity to the mono-polar solvents. The cells could be assumed to have more electron donating properties attributable to the presence of carboxylic groups on microbial cell surfaces (Bellon-Fontaine et al., 1996). Differences in the hydrophobicity of the strains further suggested variation in the structure and surface composition of each strain (Pan, Li, \& Liu, 2006).

\subsection{Adhesion to Porcine Mucin and Caco-2 Cells}

Table 2. Adhesion of Lactobacillus plantarum strains (LpTx, NGL5 and NGL7) to porcine mucin

\begin{tabular}{|c|c|c|c|c|c|}
\hline \multirow[t]{2}{*}{ LAB } & \multicolumn{3}{|c|}{ *Adhesion relative to Mucin $\mathrm{OD}_{403}$} & \multicolumn{2}{|c|}{$\begin{array}{l}\text { Viable cell count at } 37^{\circ} \mathrm{C} \text { after } \\
2 \mathrm{~h}\left(\log _{10} \mathrm{CFU} \mathrm{mL} \mathrm{mL}^{-1}\right)\end{array}$} \\
\hline & $37^{\circ} \mathrm{C}(2 \mathrm{~h})$ & $37^{\circ} \mathrm{C}(20 \mathrm{~h})$ & $4^{\circ} \mathrm{C}(20 \mathrm{~h})$ & Initial cells & Adhered cells \\
\hline NGL5 & $0.72 \pm 0.03^{b}$ & $1.07 \pm 0.22^{\mathrm{a}}$ & $0.11 \pm 0.13^{\mathrm{b}}$ & $8.43 \pm 0.07^{\mathrm{a}}$ & $6.52 \pm 0.02^{\mathrm{a}}$ \\
\hline NGL7 & $0.62 \pm 0.04^{\mathrm{b}}$ & $0.80 \pm 0.07^{\mathrm{a}}$ & $0.32 \pm 0.27^{b}$ & $8.22 \pm 0.02^{\mathrm{bc}}$ & $6.60 \pm 0.11^{\mathrm{a}}$ \\
\hline LpTx & $1.45 \pm 0.06^{\mathrm{a}}$ & $0.43 \pm 0.09^{b}$ & $0.06 \pm 0.09^{\mathrm{b}}$ & $8.15 \pm 0.01^{\mathrm{c}}$ & $6.51 \pm 0.11^{\mathrm{a}}$ \\
\hline L. reuteri NCIB 11951 & $0.72 \pm 0.04^{\mathrm{b}}$ & $0.86 \pm 0.04^{\mathrm{a}}$ & $1.40 \pm 0.39^{\mathrm{a}}$ & $8.25 \pm 0.02^{\mathrm{b}}$ & $6.61 \pm 0.10^{\mathrm{a}}$ \\
\hline
\end{tabular}

Values with same superscript in the same column do not differ significantly $(\mathrm{p} \leq 0.05)$.

*Adhesion $=\left(O D_{m L}-O D_{m}\right) / O D_{m} . \mathrm{N}=3 \pm \mathrm{SD}$.

NGL5 and NGL7 - L. plantarum strains isolated from akamu-a Nigerian fermented maize food

LPTX - Commercial probiotic strain isolated from a probiotic food supplement 


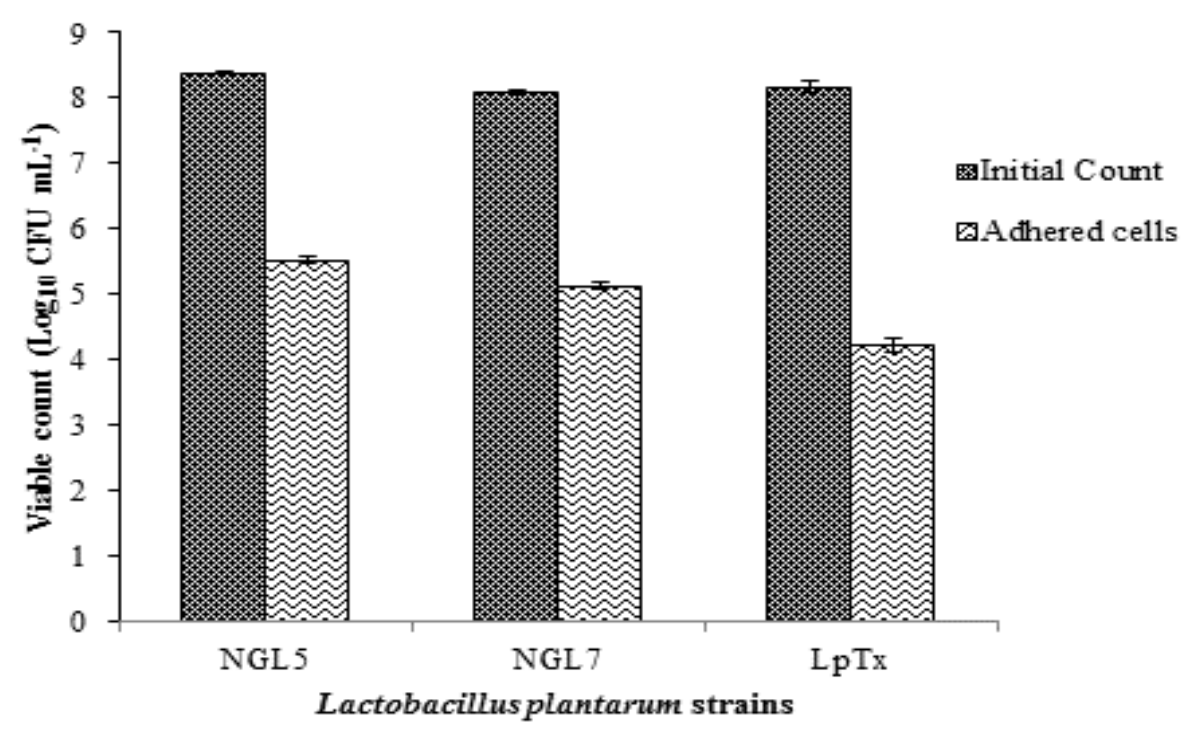

Figure 1. Adhesion of L. plantarum strains (LpTx, NGL5 and NGL7) to Caco-2 cells

NGL5 and NGL7 - L. plantarum strains isolated from akamu-a Nigerian fermented maize

LPTX - Commercial probiotic strain isolated from a probiotic food supplement

Table 2 presents the adhesion of the L. plantarum strains to porcine mucin. Adhesion of the L. plantarum strains was significantly $(p \leq 0.05)$ higher at $37^{\circ} \mathrm{C}(\geq 0.43)$ than at $4^{\circ} \mathrm{C}(\leq 0.32)$. The results obtained using the optical density method revealed that the adhesion for the test organisms at $37^{\circ} \mathrm{C}$ did not differ significantly $(\mathrm{p} \leq 0.05)$ from that of the standard L. reuteri NCIB $11951(0.72$ after $2 \mathrm{~h}$ and 0.86 after $20 \mathrm{~h})$. The probiotic strain at $37^{\circ} \mathrm{C}$ had significantly $(\mathrm{p} \leq 0.05)$ the highest adhesion after $2 \mathrm{~h}$ and significantly $(\mathrm{p} \leq 0.05)$ the lowest after $20 \mathrm{~h}$. Adhesion after $2 \mathrm{~h}$ at $37^{\circ} \mathrm{C}$ was taken as a reference condition and the adhered cells ranged between $6.51-6.61$ $\log _{10}$ CFU mL ${ }^{-1}$ for LpTx and L. reuteri NCIB 11951 respectively. There was no significant difference in the adhered cells for all the organisms. In Figure 1 the adherent viable counts on the Caco- 2 cells ranged between 4.22 and $5.53 \log _{10} \mathrm{CFU} \mathrm{mL} \mathrm{L}^{-1}$ for LpTx and NGL5 respectively.

The $L$. plantarum strains were able to adhere to porcine mucin $(\geq 0.62$ from the optical density assay and $\geq 6.51$ $\log _{10} \mathrm{CFU} \mathrm{mL}{ }^{-1}$ for viable cell count). Some studies have revealed that effective binding of $L$. plantarum strains are mediated by the secretion of extracellular protein (Hevia et al., 2013; Sánchez, González-Tejedo, Ruas-Madiedo, Urdaci, \& Margolles, 2011). It could be suggested that the L. plantarum strains in this present study may possess proteins with adherence capabilities in addition to the binding receptors of the mucin. The isolated $L$. plantarum strains were characterised with the ability to also adhere to Caco- 2 cell linings. The adhesion of the L. plantarum strains to the epithelial cell culture (Caco-2) based on the enumeration of the bacterial colonies in this study indicated that $4-6 \log _{10} \mathrm{CFU} \mathrm{mL}{ }^{-1}$ were adherent to the Caco- 2 cells. This was higher than values reported in similar analysis for L. plantarum ACA-DC 112 (Maragkoudakis, Miaris, et al., 2006) and some other Lactobacillus spp. (Monteagudo-Mera et al., 2012). The adhesion of the isolated endogenous L. plantarum strains (NGL5 and NGL7) to Caco-2 cells was significantly ( $\mathrm{p} \leq 0.05)$ higher than the probiotic strain (LpTx). The type of strain and not its origin may be an influencing factor to adherent properties. Considering the adhesion potential of the isolated Nigerian akamu L. plantarum strains (NGL5 and NGL7) in comparison with the commercial probiotic strain (LpTx), it could be suggested that the L. plantarum strains (NGL5 and NGL7) would be able to utilize the binding sites and possibly proliferate and prevent colonization by pathogens in the GIT. There was an observed correlation $(\mathrm{p} \leq 0.01)$ in Table 3 between hydrophobicity and adhesion to porcin mucin especially with Ethyl acetate $(r=0.88)$. Increase in hydrophobicity would imply more ability to adhere to mucin. This confirmed the report that cell surface hydrophobicity offers that competitive advantage important for bacterial persistence in the gut (Vinderola \& Reinheimer, 2003). 
Table 3. Correlation between hydrophobicity, adhesion to mucin and Caco 2 cells

\begin{tabular}{lllllll}
\hline & & \multicolumn{2}{c}{ Adhesion } & \multicolumn{3}{c}{ Hydrophobicity } \\
\cline { 3 - 7 } Adhesion & Mucin $^{\mathrm{a}}$ & -0.42 & & & & \\
& & $(0.26)$ & & & & \\
Hydrophobicity & Hexadecane & 0.32 & 0.50 & & & \\
& & $(0.41)$ & $(0.17)$ & & & \\
& Chloroform & 0.24 & 0.57 & 1.00 & & \\
& & $(0.54)$ & $(0.11)$ & $(0.00)^{*}$ & & \\
& Ethyl acetate & -0.30 & 0.80 & 0.81 & 0.85 & \\
& & $(0.44)$ & $(0.01)^{*}$ & $(0.01)^{*}$ & $(0.00)^{*}$ & \\
& Hexane & -0.16 & 0.74 & 0.88 & 0.92 & 0.99 \\
& $(0.68)$ & $(0.02)$ & $(0.00)^{*}$ & $(0.00)^{*}$ & $(0.00)^{*}$ \\
\hline
\end{tabular}

a - Values used are the adhered viable cells

$* \mathrm{p} \leq 0.05$ signified correlation between variables.

\subsection{Gelatinase and Haemolytic Activity}

The Lactobacillus plantarum strains (NGL5, NGL7 and LpTx) were unable to hydrolyse gelatine. The haemolytic activities of the $L$. plantarum strains and the pathogens were shown in Figure 2 . The strains of $L$. plantarum exhibited no haemolytic activity ( $\gamma$-haemolysis), while greenish coloration $(\alpha$-haemolysis) was observed for S. Enteritidis NCTC 5188. E. coli NCTC 11560 had prolific growth with clear zones around its colonies ( $\beta$-haemolysis).
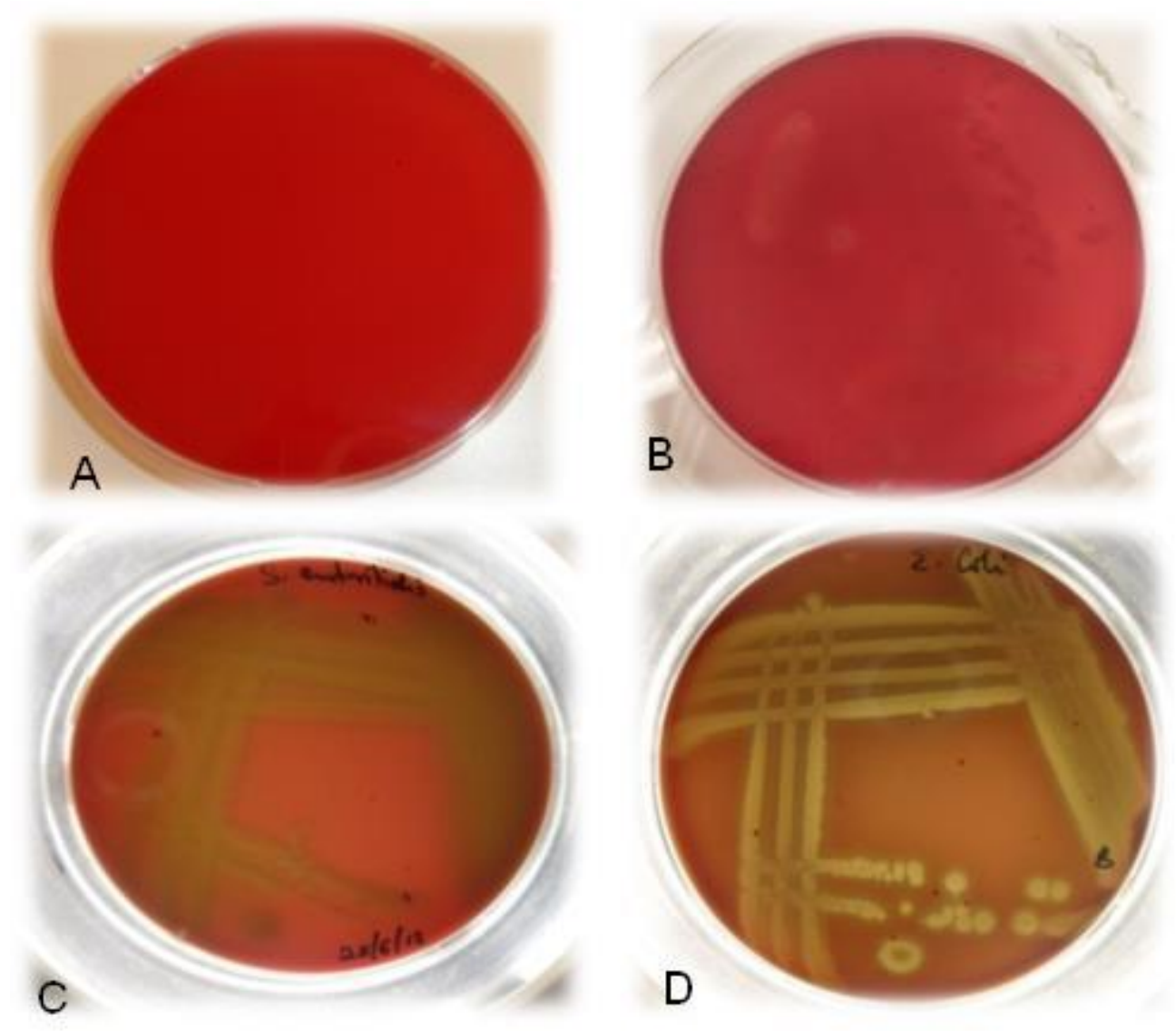

Figure 2. Demonstration of haemolytic activity: (A) Fresh blood agar, (B) $\gamma$-haemolysis of Lactobacillus plantarum strain, (C) $\alpha$-haemolysis of Salmonella enteritidis NCTC 5188 and (D) $\beta$-haemolysis of Escherichia coli NCTC 11560 
In line with the FAO/WHO, (2002) recommended safety attributes, the L. plantarum strains did not exhibit gelatinase and haemolytic activity. This was in agreement with the report on non-haemolytic and non-gelatinase activities of strains of L. plantarum isolated from Kenyan fermented maize porridges (Kalui et al., 2009) and the non-haemolytic activity of other Lactobacillus species reported by Maragkoudakis et al., (2006) and Zhang, Li, $\& \mathrm{Li}$, (2012). This implies that the L.plantarum strains would neither derange mucus protective lining of the GIT nor cause cessation of the underlying epithelial layer. Other safety attributes that could further be investigated are resistance to antibiotics and the possession of transferable resistant genes.

The $L$. plantarum strains exhibited significant adhesion to hydrocarbons, porcine mucin and Caco-2 cells. With respect to safety issues, there was no gelatinase and haemolytic activity observed. This suggested that the $L$. plantarum strains isolated from the Nigerian fermented maize food -akamu would be able to adhere to the intestinal mucosa and epithelial cells for beneficial health effects without posing any risk.

\section{Acknowledgments}

The author acknowledges the financial support of the Rivers State Scholarship Board, Rivers State Nigeria. Also appreciated is the technical assistance of Technicians from the Microbiology Unit of Plymouth University, UK.

\section{References}

Aleljung, P., Shen, W., Rozalska, B., Hellman, U., Ljungh, ^., \& Wadström, T. (1994). Purification of collagen-binding proteins of Lactobacillus reuteri NCIB 11951. Current Microbiology, 28(4), 231-236. https://doi.org/10.1007/bf01575966

Apostolou, E., Kirjavainen, P. V., Saxelin, M., Rautelin, H., Valtonen, V., Salminen, S. J., \& Ouwehand, A. C. (2001). Good adhesion properties of probiotics: a potential risk for bacteremia? FEMS Immunology and Medical Microbiology, 31(1), 35-39. https://doi.org/10.1016/s0928-8244(01)00237-1

Baccigalupi, L., Di Donato, A., Parlato, M., Luongo, D., Carbone, V., Rossi, M., ... De Felice, M. (2005). Small surface-associated factors mediate adhesion of a food-isolated strain of Lactobacillus fermentum to Caco-2 cells. Research in Microbiology, 156(7), 830-836. https://doi.org/10.1016/j.resmic.2005.05.001

Bellon-Fontaine, M. N., Rault, J., \& van Oss, C. J. (1996). Microbial adhesion to solvents: a novel method to determine the electron-donor/electron-acceptor or Lewis acid-base properties of microbial cells. Colloids and Surfaces B: Biointerfaces, 7(1-2), 47-53. https://doi.org/10.1016/0927-7765(96)01272-6

Del Re, B., Sgorbati, B., Miglioli, M., \& Palenzona, D. (2000). Adhesion, autoaggregation and hydrophobicity of 13 strains of Bifidobacterium longum. Letters in Applied Microbiology, 31, 438-442.

FAO/WHO. (2002). Guidelines for the evaluation of probiotics in food. A Joint FAO/WHO Working Group Report. Retrieved from London

Harrigan, W. F. (Ed.) (1998). Laboratory Methods in Food Microbiology (3rd ed.). London: Academic Press Ltd.

Hevia, A., Martínez, N., Ladero, V., Álvarez, M. A., Margolles, A., \& Sánchez, B. (2013). An extracellular serine/threonine-rich protein from Lactobacillus plantarum NCIMB 8826 is a novel aggregation-promoting factor with affinity to mucin. Applied and Environmental Microbiology, 79(19), 6059-6066. https://doi.org/10.1128/aem.01657-13

Jonsson, H., Ström, E., \& Roos, S. (2001). Addition of mucin to the growth medium triggers mucus-binding activity in different strains of Lactobacillus reuteri in vitro. FEMS Microbiology Letters, 204(1), 19-22. https://doi.org/10.1016/s0378-1097(01)00369-x

Juge, N. (2012). Microbial adhesins to gastrointestinal mucus. Trends in Microbiology, 20(1), 30-39. https://doi.org/10.1016/j.tim.2011.10.001

Kalui, C. M., Mathara, J. M., Kutima, P. M., Kiiyukia, C., \& Wongo, L. E. (2009). Functional characteristics of Lactobacillus plantarum and Lactobacillus rhamnosus from Ikii, a Kenyan traditional fermented maize porridge. African Journal of Biotechnology, 8(18), 4363-4373.

Kirjavainen, P. V., Ouwehand, A. C., Isolauri, E., \& Salminen, S. J. (1998). The ability of probiotic bacteria to bind to human intestinal mucus. FEMS Microbiology Letters, 167(2), 185-189. https://doi.org/10.1016/s0378-1097(98)00387-5

Kos, B., Šušković, J., Vuković, S., Šimpraga, M., Frece, J., \& Matošić, S. (2003). Adhesion and aggregation ability of probiotic strain Lactobacillus acidophilus M92. Journal of Applied Bacteriology, 94, 981-987.

Lin, W.-H., Wu, C.-R., Fang, T. J., Lee, M.-S., Lin, K.-L., Chen, H.-C., ... Hseu, Y.-C. (2011). Adherent 
properties and macrophage activation ability of 3 strains of lactic acid bacteria. Journal of Food Science, 76(1), M1-M7. https://doi.org/10.1111/j.1750-3841.2010.01875.x

Liu, Y., Yang, S.-F., Li, Y., Xu, H., Qin, L., \& Tay, J.-H. (2004). The influence of cell and substratum surface hydrophobicities on microbial attachment. Journal of Biotechnology, 110(3), 251-256.

Maragkoudakis, P. A., Miaris, C., Rojez, P., Manalis, N., Magkanari, F., Kalantzopoulos, G., \& Tsakalidou, E. (2006). Production of traditional Greek yoghurt using Lactobacillus strains with probiotic potential as starter adjuncts. International Dairy Journal, 16(1), 52-60. https://doi.org/10.1016/j.idairyj.2004.12.013

Maragkoudakis, P. A., Zoumpopoulou, G., Miaris, C., Kalantzopoulos, G., Pot, B., \& Tsakalidou, E. (2006). Probiotic potential of Lactobacillus strains isolated from dairy products. International Dairy Journal, 16(3), 189-199. https://doi.org/10.1016/j.idairyj.2005.02.009

Mathara, J. M., Schillinger, U., Guigas, C., Franz, C., Kutima, P. M., Mbugua, S. K., ... Holzapfel, W. H. (2008). Functional characteristics of Lactobacillus spp. from traditional Maasai fermented milk products in Kenya. International Journal of Food Microbiology, 126(1-2), 57-64.

Monteagudo-Mera, A., Rodríguez-Aparicio, L., Rúa, J., Martínez-Blanco, H., Navasa, N., García-Armesto, M. R., \& Ferrero, M. Á. (2012). In vitro evaluation of physiological probiotic properties of different lactic acid bacteria strains of dairy and human origin. Journal of Functional Foods, 4(2), 531-541. https://doi.org/10.1016/j.jff.2012.02.014

Obinna-Echem, P. C., Kuri, V., \& Beal, J. (2014). Evaluation of the microbial community, acidity and proximate composition of Akamu, a fermented maize food. Journal of the Science of Food and Agriculture, 94(2), 331-340. https://doi.org/10.1002/jsfa.6264

Pan, W.-H., Li, P.-L., \& Liu, Z. (2006). The correlation between surface hydrophobicity and adherence of Bifidobacterium strains from centenarians' faeces. Anaerobe, 12(3), 148-152. https://doi.org/10.1016/j.anaerobe.2006.03.001

Roos, S., Karner, F., Axelsson, L., \& Jonsson, H. (2000). Lactobacillus mucosae sp. nov., a new species with in vitro mucus-binding activity isolated from pig intestine. International Journal of Systematic and Evolutionary Microbiology, 50, 251-258.

Schillinger, U., Guigas, C., \& Heinrich Holzapfel, W. (2005). In vitro adherence and other properties of lactobacilli used in probiotic yoghurt-like products. International Dairy Journal, 15(12), 1289-1297. https://doi.org/10.1016/j.idairyj.2004.12.008

Svensson, O., \& Arnebrant, T. (2010). Mucin layers and multilayers - Physicochemical properties and applications. Current Opinion in Colloid \&amp; Interface Science, 15(6), 395-405. https://doi.org/10.1016/j.cocis.2010.05.015

Sánchez, B., González-Tejedo, C., Ruas-Madiedo, P., Urdaci, M. C., \& Margolles, A. (2011). Lactobacillus plantarum extracellular chitin-binding protein and its role in the Interaction between chitin, Caco-2 cells, and mucin. Applied and Environmental Microbiology, 77(3), 1123-1126. https://doi.org/10.1128/aem.02080-10

Uchida, H., Kinoshita, H., Kawai, Y., Kitazawa, H., Miura, K., Shiiba, K., ... Saito, T. (2006). Lactobacilli binding human A-antigen expressed in intestinal mucosa. Research in Microbiology, 157(7), 659-665. https://doi.org/10.1016/j.resmic.2006.03.001

Vinderola, C. G., \& Reinheimer, J. A. (2003). Lactic acid starter and probiotic bacteria: a comparative "in vitro" study of probiotic characteristics and biological barrier resistance. Food Research International 36, 895-904.

Wang, B., Wei, H., Yuan, J., Li, Q., Li, Y., Li, N., \& Li, J. (2008). Identification of a surface protein from Lactobacillus reuteri JCM1081 that adheres to porcine gastric mucin and human enterocyte-like HT-29 cells. Current Microbiology, 57(1), 33-38. https://doi.org/10.1007/s00284-008-9148-2

Xie, N., Zhou, T., \& Li, B. (2012). Kefir yeasts enhance probiotic potentials of Lactobacillus paracasei H9: The positive effects of coaggregation between the two strains. Food Research International, 45(1), 394-401. https://doi.org/10.1016/j.foodres.2011.10.045

Zar, J. H. (Ed.) (1999). Biostatistical Analysis (4th ed.). London, UK: Prentice Hall.

Zhang, D., Li, R., \& Li, J. (2012). Lactobacillus reuteri ATCC 55730 and L22 display probiotic potential in vitro and protect against Salmonella-induced pullorum disease in a chick model of infection. Research in 
Veterinary Science, 93(1), 366-373. https://doi.org/10.1016/j.rvsc.2011.06.020

Zhou, J. S., Gopal, P. K., \& Gill, H. S. (2001). Potential probiotic lactic acid bacteria Lactobacillus rhamnosus (HN001), Lactobacillus acidophilus (HN017) and Bifidobacterium lactis (HN019) do not degrade gastric mucin in vitro. International Journal of Food Microbiology, 63(1-2), 81-90. https://doi.org/10.1016/s0168-1605(00)00398-6

Zita, A., \& Hermansson, M. (1997). Determination of bacterial cell surface hydrophobicity of single cells in cultures and in wastewater in situ. FEMS Microbiology Letters, 152(2), 299-306. https://doi.org/10.1016/s0378-1097(97)00214-0

\section{Copyrights}

Copyright for this article is retained by the author(s), with first publication rights granted to the journal.

This is an open-access article distributed under the terms and conditions of the Creative Commons Attribution license (http://creativecommons.org/licenses/by/4.0/). 